\title{
Analysis of perceptions and attitudes of scheduled commercial bank personnel toward provision of credit to poor and toward financial inclusion process in India
}

\section{T. Ravikumar}

Dept. Of Management Studies, Christ University, Bangalore

Email address:

bhagavathnaren@gmail.com (T. Ravikumar)

\section{To cite this article:}

T. Ravikumar. Analysis of Perceptions and Attitudes of Scheduled Commercial Bank Personnel Toward Provision of Credit to Poor and Toward Financial Inclusion Process in India. Journal of Investment and Management. Vol. 1, No. 1, 2012, pp. 1-11. doi: $10.11648 /$ j.jim.20120101.11

\begin{abstract}
A bank's role in providing financial services to the poor is debatable. There are no grounds to believe that the banks have been willing or able to operate as development institutions for the poor. McKee (1989, p. 997) noted, however, that given the resources of the banking system, "changing its behavior even at the margin offers the potential to improve the livelihoods of millions of poor people." McKee's view is particularly resonant for India where, although the rural banking sector has an unrivalled physical presence with nearly 33,000 Commercial and Regional Rural Bank branches, the quality of outreach to the poor leaves scope for improving the low recovery rates, impaired viability of bank branches, varying degrees of bureaucratization and politicization and erosion in staff morale. In addition to physical presence, banks offer advantages by being regulated institutions with established administrative and accounting systems, by not being dependent on scarce and volatile donor resources, and by offering a range of financial services. Moreover, for reasons ranging from enhancement of public image to diversification into new markets, some banks are increasingly interested in the microfinance sector. However, when banking reforms required to promote financial inclusion are discussed in lot by academicians, finance experts and RBI, insufficient attention is paid to the possibility that the attitudes of staff, at both branch and institutional levels, may constrain the provision of financial services to the poor and their role in implementation of financial inclusion initiatives. These aspects are the focus of the present research article.
\end{abstract}

Keywords: Perceptions, Attitudes, Scheduled Commercial Bank Personnel, Provision Of Credit, Financial Inclusion, India

\section{Introduction}

Although banking financial services are seen as important instruments in reducing poverty, significant segments of urban and rural populations are not served by conventional financial institutions (K.C. Chakrabarthy). Perceptions of high costs and high risk divert banks from lending to small scale operators in rural areas. Moreover, in India "the failure of the specialized rural credit institutions to become self-financing under cheap credit policy makes them deviate, ultimately, from their pre-laid objective of lending to the rural poor".

The informal financial sector continues to serve the rural and urban poor in India despite massive expansion of institutional credit. Although informal agents, like pawnbrokers, offer advantages to poor clients in terms of speed, minimal paperwork, small and multiple loan provision, and inevitable presence in local culture, they generally provide short-term, low value, and high interest finance within a highly localized area of operations. While the high quality of financial services from NGOs and other microfinance institutions (MFIs) in India are recognized their combined outreach is less than $0.5 \%$ of the population.

A bank's role in providing financial services to the poor is debatable. For Bangladesh, McGregor (1988) suggested there are no grounds to believe that the banks have been willing or able to operate as development institutions for the poor.

McKee (1989, p. 997) noted, however, that given the resources of the banking system, "changing its behavior even at the margin offers the potential to improve the livelihoods of millions of poor people."

McKee's view is particularly resonant for India where, 
although the rural banking sector has an unrivalled physical presence with nearly 33,000 Commercial and Regional Rural Bank branches, the quality of outreach to the poor leaves scope for improving the low recovery rates, impaired viability of bank branches, varying degrees of bureaucratization and politicization, and erosion in staff morale.

In addition to physical presence, banks offer advantages by being regulated institutions with established administrative and accounting systems, by not being dependent on scarce and volatile donor resources, and by offering a range of financial services. Moreover, for reasons ranging from enhancement of public image to diversification into new markets, some banks are increasingly interested in the microfinance sector.

However, when banking reforms required to promote financial inclusion are discussed in lot by academicians, finance experts and RBI, insufficient attention is paid to the possibility that the attitudes of staff, at both branch and institutional levels, may constrain the provision of financial services to the poor and their role in implementation of financial inclusion initiatives. These aspects are the focus of the present research article.

Attitude of staff has been studied in different countries from different viewpoints. For example, "to meet the needs of the poor, the behavior of an organization's staff toward their clients requires revision and tailoring". Johnson and Rogaly (1997) noted how disdain and contempt meted out to the poor by bank staff may not have a monetary cost, but the acts do have a cost all the same. Access to banks by small-scale borrowers can be inhibited by the nature, characteristics, and requirements of these formal financial institutions.

\section{Statement of the Problem}

In India, financial inclusion initiatives of formal financial institutions primarily banking sector have been outsourced, by and large, to intermediaries like Micro Finance Institutions (MFIs) and Self Help Groups (SHGs). Although this model has worked considerably well, its combined outreach is less than $0.5 \%$ of the population and it needs some refinement. Further, Government of India and RBI have been taking number of initiatives and measures to bring financially excluded people of India in to formal financial structure like opening of no-frills account, Know Your Customer (KYC), priority lending etc. The core responsibility of implementing financial inclusion initiatives lies on bank personnel. In reality, bank personnel do not consider financial inclusion initiatives as responsibility, but, as a nuisance.

"Most of bank personnel feel that implementation of financial inclusion initiatives is a nuisance and treat low income households as an intrusion in to their time and their business". The above quoted statement was delivered by Dr. Subbarao, Governor, RBI while addressing to bankers at a platinum jubilee function of Indian Overseas Bank in Chennai on 5th July, 2012. Therefore, it is essential to study about bank personnel especially commercial bank person- nel's perceptions and attitudes toward financial inclusion initiatives and toward provision of credit to the poor people. The present article has made an attempt in this regard.

\section{Objectives of the Study}

The fundamental objectives of this study can be summarized as

1. To examine perceptions and attitudes of bank personnel toward provision of credit to poor based on demographic and work related variables.

2. To investigate perceptions and attitudes of bank personnel toward financial inclusion process in India based on demographic and work related variables.

3. To study about relationship between perceptions and attitudes of bank personnel toward financial inclusion process in India and perceptions and attitudes of bank personnel toward provision of credit to poor.

\section{Research Methodology}

The study involves examination of perceptions and attitudes of scheduled commercial bank personnel toward financial inclusion process and toward provision of financial services to the poor. Therefore, for the purpose of this, primary data have been used.

This study has adopted survey data based approach (Questionnaire method) and data are collected from the respondents through traditional well-structured questionnaire to measure perceptions and attitudes of scheduled commercial bank personnel toward financial inclusion process and toward provision of financial services to the poor.

\subsection{Measurement of Perceptions and Attitudes of Sche- duled Commercial Bank Personnel toward Provision of Financial Services to the Poor}

The researcher has presented seventeen statements in Likert's five points scale (Questionnaire - I: PART - B Question - 13; Items 13.1 to 13.17) to measure perceptions and attitudes of scheduled commercial bank personnel toward provision of financial services to the poor in terms of following variables.

A) Bank personnel views on provision of credit to poor Items $13.1-13.10$

B) Bank personnel and poor client relationship - Items $13.11-13.17$

\subsection{Measurement of Perceptions and Attitudes of Sche- duled Commercial Bank Personnel toward Financial Inclusion Process}

The researcher has presented fifteen statements in Likert's five points scale (Questionnaire - I: PART - B - Question 13; Items 13.18 to 13.32) to measure perceptions and attitudes of scheduled commercial bank personnel toward financial inclusion process in India in terms of following 
variables. Further, an open ended question (Questionnaire I: PART - B - Question - 14) has been presented to obtain the view of bank personnel toward financial inclusion process in India.

A) Awareness about financial inclusion - Items 13.18 13.19

B) Implementation of financial inclusion initiatives Items $13.20-13.21$

C) Bank personnel views on financial inclusion - Items $13.22-13.32$

Demographic and job related variables are presented in the questionnaire (Questionnaire - I: Part - A; Questions 1 to 12 ) to measure the perceptions and attitudes of scheduled commercial bank personnel toward financial inclusion process and toward provision of financial services to the poor.

\subsection{Sampling Frame}

Primary data needed for the study have been collected through questionnaires issued to people of Tamilnadu who are the sample for the study. Sample consists of bank personnel belonging to different area and different designations. Convenience sampling has been adopted considering the availability and approachability of bank personnel for the purpose of data collection effort. However, due consideration is exercised for the proportionate representation of the sample population.

\subsection{Pretesting of the Questionnaire and Main Study}

The questionnaire was pretested by administering it to 38 bank personnel selected at random in Tamilnadu. The data obtained was verified for the reliability of the questionnaire by computing Cronbach's alpha co-efficient.

The results are as follows;

Perceptions and attitudes of bank personnel toward provision of credit to the poor

Perceptions and attitudes of bank personnel toward financial inclusion process

0.812

The above reliability co-efficient may be considered satisfactory. Then, the final version of questionnaire was prepared and used for the study. Main study was conducted among 62 bank personnel.

\subsection{Framework of Data Analysis}

Mean scores, median, percentages and standard deviations were also calculated for analysis of perceptions and attitudes of scheduled commercial bank personnel in Tamilnadu toward provision of credit to poor people and toward financial inclusion process in India in relation with demographic and work related characteristics of bank personnel in Tamilnadu.

Further, One way ANOVA (F test) and students' " $t$ " test were used to identify the significant differences in the perceptions and attitudes of scheduled commercial bank personnel toward provision of credit and toward financial inclusion process in India on the basis of their demographic and work related variables.

Multiple regression analysis was used to identify perceptions and attitudes toward provision of credit to the poor.

\section{Data Analysis and Interpretation}

\subsection{Analysis of Demographic and Work Profile of the Respondents}

The demographic and work related characteristics reveal certain significant features of the respondents which are summarized as follows;

1. Male respondents constitute $80.6 \%$ of the sample.

2. $61.3 \%$ of the respondents are below the age of 35 years which indicates significant deployment of young people in the banking sector.

3. $64.5 \%$ of the respondents are unmarried.

4. Majority of bank personnel $(62.9 \%)$ has post graduate educational qualification.

5. Majority of the respondents $(62.9 \%)$ is bank branch managers.

6. $69.4 \%$ of the respondents have less than 15 years of service in banking sector and $12.9 \%$ of the respondents have more than 30 years of service in sector.

7. $46.8 \%$ of sample bank personnel's native place is metropolitan area while $35.5 \%$ of sample bank personnel's native place is rural area.

8. $67.7 \%$ of sample bank personnel belong to middle class family before their employment and $22.6 \%$ of sample bank personnel belong to poor family before their employment.

9. $56.5 \%$ of sample bank personnel work in public sector bank, $25.8 \%$ of sample bank personnel work in private sector bank and $17.7 \%$ of sample bank personnel work in Regional rural bank.

10. $74.2 \%$ of sample bank is located in remote area and urban area (37.1\% each), $17.7 \%$ of sample bank is located in rural area and $8.1 \%$ of sample bank is located in semi-urban area.

\subsection{Analysis of Perceptions and Attitudes of Bank Per- sonnel toward Provision of Credit to Poor Based on Demographic and Work Related Variables}

Scheduled commercial banks play vital role in promotion of financial inclusion in India. Now a day, scheduled commercial banks involve in implementation of financial inclusion initiatives vigorously by opening no-frills account, adopting villages etc. But, still there is a perception that bank personnel are more interested in serving wealthy people and companies than serving poor people and small scale enterprises. Therefore, the study has made an attempt to study and analyze perceptions and attitudes of bank personnel toward provision of credit to poor.

In this part of the article, perceptions and attitudes of bank personnel toward provision of credit to poor based on demographic and work related variables are empirically analyzed. 
Table 1. Demographic and work related characteristics of bank personnel.

\begin{tabular}{|c|c|c|c|c|}
\hline No & Particulars & & $\begin{array}{l}\text { No. of } \\
\text { Respondents }\end{array}$ & Percentages \\
\hline \multirow[t]{4}{*}{1} & \multicolumn{4}{|l|}{ Gender } \\
\hline & \multicolumn{2}{|l|}{ Male } & 50 & 80.60 \\
\hline & \multicolumn{2}{|l|}{ Female } & 12 & 19.40 \\
\hline & \multicolumn{2}{|l|}{ Total } & 62 & 100.00 \\
\hline \multirow[t]{4}{*}{2} & \multicolumn{4}{|l|}{ Marital Status } \\
\hline & \multicolumn{2}{|l|}{ Married } & 22 & 35.50 \\
\hline & \multicolumn{2}{|l|}{ Unmarried } & 40 & 64.50 \\
\hline & \multicolumn{2}{|l|}{ Total } & 62 & 100.00 \\
\hline \multirow[t]{5}{*}{3} & \multicolumn{4}{|l|}{ Age Group } \\
\hline & \multicolumn{2}{|l|}{ Less Than 35 Years } & 38 & 61.30 \\
\hline & \multicolumn{2}{|l|}{36 Years To 50 Years } & 11 & 17.70 \\
\hline & \multicolumn{2}{|l|}{51 Years To 60 Years } & 13 & 21.00 \\
\hline & \multicolumn{2}{|l|}{ Total } & 62 & 100.00 \\
\hline \multirow[t]{5}{*}{4} & \multicolumn{4}{|c|}{ Educational Qualification } \\
\hline & UG & & 8 & 12.90 \\
\hline & PG & & 39 & 62.90 \\
\hline & Professional Qualific & tion & 15 & 24.20 \\
\hline & Total & & 62 & 100.00 \\
\hline \multirow[t]{5}{*}{5} & \multicolumn{4}{|l|}{ Designation } \\
\hline & Branch Officer & & 17 & 27.40 \\
\hline & Branch Accountant & & 6 & 09.70 \\
\hline & Branch Manager & & 39 & 62.90 \\
\hline & Total & & 62 & 100.00 \\
\hline \multirow[t]{5}{*}{6} & \multicolumn{4}{|c|}{ Number Of Years Of Service } \\
\hline & Less Than 15 Years & & 43 & 69.40 \\
\hline & 16 Years To 30 Years & & 11 & 17.70 \\
\hline & More Than 30 Years & & 8 & 12.90 \\
\hline & Total & & 62 & 100.00 \\
\hline 7 & Place Of Native & & & \\
\hline & Remote Area & & 5 & 08.10 \\
\hline & Rural Area & & 22 & 35.50 \\
\hline & Urban Area & & 6 & 09.70 \\
\hline & Metropolitan & & 29 & 46.80 \\
\hline & Total & & 62 & 100.00 \\
\hline 8 & Economic Status Of $\mathrm{I}$ & amily 1 & 3efore Employn & nent \\
\hline & Well Off & & 6 & 09.70 \\
\hline & Middle Class & & 42 & 67.70 \\
\hline & Poor & & 14 & 22.60 \\
\hline & Total & & 62 & 100.00 \\
\hline 9 & Type Of Bank & & & \\
\hline & Public Sector Bank & & 35 & 56.50 \\
\hline & Private Sector Bank & & 16 & 25.80 \\
\hline & Regional Rural Bank & & 11 & 17.70 \\
\hline & Total & & 62 & 100.00 \\
\hline 10 & Location Of Bank & & & \\
\hline & Remote Area & 23 & & 37.10 \\
\hline & Rural Area & 11 & & 17.70 \\
\hline & Semi-Urban Area & 5 & & 08.10 \\
\hline & Urban Area & 23 & & 37.10 \\
\hline
\end{tabular}

Table 2. Gender and perceptions and attitudes of bank personnel toward provision of credit to poor.

\begin{tabular}{llllll}
\hline Gender & $\begin{array}{l}\text { Mean } \\
\text { value }\end{array}$ & F value & t value & P value & Result \\
\hline Male & 71.0118 & & & & \\
Female & 77.0588 & 2.419 & -2.825 & 0.125 & Not significant \\
\hline
\end{tabular}

Source: Primary data, ${ }^{*}$ At $1 \%$ level of significance ${ }^{* *}$ At $5 \%$ level of significance.

The above Students " $t$ " test reveals that there is no significant difference between gender of sample bank personnel and their perceptions and attitudes toward provision of credit to poor. It indicates that both male and female bank personnel have same kind of perceptions and attitudes toward provision of credit to poor. Mean scores of the above table show that female bank personnel have more positive perceptions and attitudes (77.06) toward provision of credit to the poor than male bank personnel (71.01). It confirms the belief that women are more kind towards downtrodden people than men.

Table 3. Age and perceptions and attitudes of bank personnel toward provision of credit to poor.

\begin{tabular}{lllll}
\hline Age & $\begin{array}{l}\text { Mean } \\
\text { Value }\end{array}$ & F value & P Value Result \\
\hline Less than 35 years & 69.8762 & & & \\
36 years to 50 years & 81.9251 & 1.181 & 0.328 & $\begin{array}{l}\text { Not Signif- } \\
\text { icant }\end{array}$ \\
51 years to 60 years & 70.6787 & & & . \\
\hline
\end{tabular}

Source: Primary data, *At $1 \%$ level of significance**At $5 \%$ level of significance.

The above one way ANOVA table indicates that there is no significant difference between age of sample bank personnel and their perceptions and attitudes toward provision of credit to poor. It shows that sample bank personnel have same level of perceptions and attitudes toward provision of credit to the poor. Mean scores indicate that bank personnel who are in the age group of 36 years to 50 years have more positive perceptions and attitudes (81.92) toward provision of credit to the poor than bank personnel who are in the age group of 51 years to 60 years (70.67) and bank personnel who are in the age group of less than 35 years (69.87).

Table 4. Marital status and perceptions and attitudes of bank personnel toward provision of credit to poor.

\begin{tabular}{llllll}
\hline $\begin{array}{l}\text { Marital } \\
\text { status }\end{array}$ & $\begin{array}{l}\text { Mean } \\
\text { value }\end{array}$ & F value & t value & P value & Result \\
\hline Married & 75.9893 & 1.171 & 3.430 & 0.283 & $\begin{array}{l}\text { Not } \\
\text { significant }\end{array}$ \\
Unmarried & 70.0882 & & & \\
\hline
\end{tabular}

Source: Primary data, *At 1\% level of significance**At $5 \%$ level of signi- 
ficance.

The one way ANOVA Table - 4 reveals that there is no significant difference between marital status of sample bank personnel and their perceptions and attitudes toward provision of credit to the poor. Therefore, both married and unmarried bank personnel have same level of perceptions and attitudes toward provision of credit to the poor. Mean scores show that married bank personnel have more positive perceptions and attitudes (75.98) toward provision of credit to the poor than unmarried bank personnel (70.08).

Table 5. Education and perceptions and attitudes of bank personnel toward provision of credit to poor.

\begin{tabular}{lllll}
\hline Education & Mean Value & F value & P Value & Result \\
\hline UG & 70.5882 & & & \\
PG & 72.5189 & 0.237 & 0.982 & $\begin{array}{l}\text { Not } \\
\text { Pignificant }\end{array}$ \\
$\begin{array}{l}\text { Qualification } \\
\text { Qualional }\end{array}$ & 72.1569 & & & \\
\hline
\end{tabular}

Source: Primary data, *At $1 \%$ level of significance **At $5 \%$ level of significance.

The above ANOVA Table - 5 shows that there is no significant difference between educational qualification of sample bank personnel and their perceptions and attitudes toward provision of credit to the poor. Therefore, bank personnel have same level of perceptions and attitudes toward provision of credit to the poor irrespective of their educational qualification. Mean scores show that bank personnel with post graduate degree have more positive perceptions and attitudes (72.28) toward provision of credit to the poor than bank personnel with professional qualification (72.15) and bank personnel with under graduate degree (70.58).

Table 6. Designation and perceptions and attitudes of bank personnel toward provision of credit to poor.

\begin{tabular}{lllll}
\hline Designation & Mean Value & F value & P Value & Result \\
\hline Branch Officer & 74.1869 & & & \\
Branch Accountant & 77.6471 & 0.158 & $0.000^{*}$ & Significant \\
Branch Manager & 70.4676 & & & \\
\hline
\end{tabular}

Source: Primary data *At 1\% level of significance **At $5 \%$ level of significance.

The above ANOVA Table - 6 shows that there is significant difference between designation of sample bank personnel and their perceptions and attitudes toward provision of credit to the poor. Therefore, bank personnel's perceptions and attitudes toward provision of credit to the poor differ on the basis of their designation. Mean scores show that branch managers have least perceptions and attitudes (70.46) toward provision of credit to the poor. On the other hand, branch accountants have more positive perceptions and attitudes (77.64) toward provision of credit to the poor and branch officers exhibit moderate positive perceptions and attitudes (74.18) toward provision of credit to the poor. Bank managers have positive perceptions and attitudes toward provision of credit to the poor, but, they show least perceptions and attitudes than bank officers and accountants. It may be because of the bank managers have more accountability and responsibility than bank officers and bank accountants to the bank management in case of default in credit given to the poor. Further, this result shows that bank mangers do not want to take risk by providing credit to the poor.

Table 7. Years of service and perceptions and attitudes of bank personnel toward provision of credit to poor.

\begin{tabular}{lllll}
\hline Years of service & Mean Value & F value & P Value & Result \\
\hline Less than 15 years & 70.1231 & & & \\
16 years to 30 years & 80.0000 & 1.583 & 0.152 & $\begin{array}{l}\text { Not } \\
\text { Significant }\end{array}$ \\
More than 30 years & 72.5000 & & & \\
\hline
\end{tabular}

Source: Primary data *At $1 \%$ level of significance**At $5 \%$ level of significance.

The above ANOVA Table - 7 shows that there is no significant difference between years of service by sample bank personnel and their perceptions and attitudes toward provision of credit to the poor. Therefore, bank personnel have same level of perceptions and attitudes toward provision of credit to the poor irrespective of their number of years of service. Mean scores show that bank personnel with 16 years to 30 years have more positive perceptions and attitudes (80.00) toward provision of credit to the poor than bank personnel with more than 30 years of service (72.50) and bank personnel with less than 15 years of service (70.12).

Table 8. Place of native and perceptions and attitudes of bank personnel toward provision of credit to poor.

\begin{tabular}{lllll}
\hline Place of native & Mean Value & F value & P Value & Result \\
\hline Remote area & 60.0000 & & & \\
Rural area & 76.4706 & 21.339 & $0.000^{*}$ & Significant \\
Urban area & 80.0000 & & & \\
Metropolitan & 69.4118 & & & \\
\hline
\end{tabular}

Source: Primary data, *At 1\% level of significance **At $5 \%$ level of significance.

The ANOVA Table -8 shows that there is significant difference between native place of sample bank personnel and their perceptions and attitudes toward provision of credit to the poor. Therefore, bank personnel's perceptions and attitudes toward provision of credit to the poor differ on the basis of their native place. Mean scores show that bank 
personnel whose native place is remote area, have least perceptions and attitudes (60.00) toward provision of credit to the poor. On the other hand, bank personnel whose native place is urban area, have more positive perceptions and attitudes (80.00) toward provision of credit to the poor followed by bank personnel whose native place is rural area (76.47) and bank personnel whose native place is metropolitan area (69.41).

Table 9. Economic status of family and perceptions and attitudes of bank personnel toward provision of credit to poor.

\begin{tabular}{lllll}
\hline $\begin{array}{l}\text { Economic status } \\
\text { of family }\end{array}$ & Mean Value & F value & P Value & Result \\
\hline Well off & 74.1176 & & & \\
Middle Class & 71.9608 & 5.797 & $.000 *$ & Significant \\
Poor & 72.0168 & & & \\
\hline
\end{tabular}

Source: Primary data, *At 1\% level of significance **At $5 \%$ level of significance.

The above ANOVA Table - 9 shows that there is significant difference between economic status of sample bank personnel's family before employment and their perceptions and attitudes toward provision of credit to the poor. Therefore, bank personnel's perceptions and attitudes toward provision of credit to the poor differ on the basis of the economic status of their family before employment. Mean scores show that bank personnel who belonged to middle class family, show least perceptions and attitudes (71.96) toward provision of credit to the poor. On the other hand, bank personnel who were well off, show more positive perceptions and attitudes (74.11) toward provision of credit to the poor followed by bank personnel who were poor (72.01).

Table 10. Type of bank and perceptions and attitudes of bank personnel toward provision of credit to poor.

\begin{tabular}{lllll}
\hline Type of Bank & Mean Value & F value & P Value & Result \\
\hline Public sector bank & 73.7479 & & & \\
Private sector bank & 70.7353 & 6.219 & $0.000^{*}$ & Significant \\
Regional rural bank & 69.3048 & & & \\
\hline
\end{tabular}

Source: Primary data, *At $1 \%$ level of significance **At $5 \%$ level of significance.

The above ANOVA Table - 10 shows that there is significant difference between types of bank in which sample bank personnel work and their perceptions and attitudes toward provision of credit to the poor. Therefore, bank personnel's perceptions and attitudes toward provision of credit to the poor differ on the basis of types of bank where they work. Mean scores show that bank personnel who work in Public sector bank show more positive perceptions and attitudes (73.75) toward provision of credit to the poor. On the other hand, bank personnel who work in Private sector bank show moderate positive perceptions and attitudes (70.73) toward provision of credit to the poor and bank personnel who work in regional rural bank show least positive perceptions and attitudes (69.30) toward provision of credit to the poor.

Table 11. Location of bank and perceptions and attitudes of bank personnel toward provision of credit to poor.

\begin{tabular}{lllll}
\hline Location of Bank & Mean Value & F value & P Value & Result \\
\hline Remote area & 66.1381 & & & \\
Rural area & 77.4332 & 21.757 & $0.000 *$ & Significant \\
Semi-urban area & 72.9412 & & & \\
Urban area & 75.5499 & & & \\
\hline
\end{tabular}

Source: Primary data, *At 1\% level of significance **At $5 \%$ level of significance.

The ANOVA Table - 11 shows that there is significant difference between location of bank where sample bank personnel work and their perceptions and attitudes toward provision of credit to the poor. Therefore, bank personnel's perceptions and attitudes toward provision of credit to the poor differ on the basis of location of bank where they work. Mean scores show that bank personnel who work in rural area bank show more positive perceptions and attitudes (77.43) toward provision of credit to the poor followed by bank personnel who work in urban area bank (75.54). On the other hand, bank personnel who work in remote area bank show least positive perceptions and attitudes (66.13) toward provision of credit to the poor followed by bank personnel who work in semi-urban area (72.94).

Differences in perceptions and attitudes of sample bank personnel toward provision of credit to the poor on the basis of their demographic and work related variables are analyzed and discussed in tables - 5.2 to 5.11 using Students " $t$ " test and one way ANOVA (F test). Based on such analysis, comprehensive conclusions can be evolved about perceptions and attitudes of sample bank personnel toward provision of credit to the poor which are as follows:

The study results exhibit that the bank personnel born in urban area, who may be either male or female and either married or unmarried, irrespective of his age, educational qualification and years of service, having well off economic status before his employment, but, works as branch accountant in public sector rural area bank shows higher positive level of perception and attitude towards provision of credit to the poor.

Conversely, the bank personnel born in remote area, who may be either male or female and either married or unmarried, irrespective of his age, educational qualification and 
years of service, having middle class economic status before his employment, but, works as branch manager in regional rural bank in remote area shows lowest positive level of perception and attitude towards provision of credit to the poor.

\subsection{Analysis of Perceptions and Attitudes of Bank Per- sonnel toward Financial Inclusion Process in India Based on Demographic and Work Related Variables}

Reserve Bank of India (RBI) and Government of India (GOI) have been taking number of policy measures and initiatives to promote financial inclusion in India in order to bring financially excluded people in to formal financial structure. In this financial inclusion process, banking sector plays vital role especially scheduled commercial banks.

The aim of financial inclusion and implementation of financial inclusion measures and initiatives revolve around banking sector. Banking sector, in turn, largely depends upon bank personnel to implement financial inclusion initiatives. Thus, the success of financial inclusion initiatives significantly depends on willingness of bank personnel to implement such initiatives. In fact, bank personnel play catalyst role in implementation of financial inclusion initiatives. Therefore, the study has made an attempt to study and analyze perceptions and attitudes of scheduled commercial bank personnel toward financial inclusion process in India.

In this part of the article, perceptions and attitudes of bank personnel toward financial inclusion in India based on demographic and work related variables are empirically analyzed.

Table 12. Gender and perceptions and attitudes of bank personnel toward financial inclusion process in India.

\begin{tabular}{llllll}
\hline Gender & Mean value & F value & t value & P value & Result \\
\hline Male & 72.0267 & 4.746 & -.417 & $0.033^{* *}$ & Significant \\
Female & 72.6667 & & & & \\
\hline
\end{tabular}

Source: Primary data, *At 1\% level of significance **At $5 \%$ level of significance.

The above Students " $t$ " test reveals that there is a significant difference between gender of sample bank personnel and their perceptions and attitudes toward financial inclusion process in India. It indicates that bank personnel differ in their perceptions and attitudes toward financial inclusion process in India. Mean scores of the above table show that female bank personnel have more positive perceptions and attitudes (72.66) toward financial inclusion process in India than male bank personnel (72.02).

Table 13. Age and perceptions and attitudes of bank personnel toward financial inclusion process in India.

\begin{tabular}{lllll}
\hline Age & Mean Value & F value & P Value & Result \\
\hline Less than 35 years & 71.1579 & 1.328 & 0.255 & Not Significant \\
36 years to 50 years & 74.6667 & & \\
\hline
\end{tabular}

\section{1 years to 60 years 72.9231}

Source: Primary data, *At 1\% level of significance **At $5 \%$ level of significance.

The one way ANOVA Table - 13 indicates that there is no significant difference between age of sample bank personnel and their perceptions and attitudes toward financial inclusion process in India. It shows that sample bank personnel have same level of perceptions and attitudes toward financial inclusion process in India. Mean scores indicate that bank personnel who are in the age group of 36 years to 50 years have more positive perceptions and attitudes (74.66) toward financial inclusion process in India than bank personnel who are in the age group of 51 years to 60 years (72.92) and bank personnel who are in the age group of less than 35 years $(71.15)$.

Table 14. Marital status and perceptions and attitudes of bank personnel toward financial inclusion process in India.

\begin{tabular}{llllll}
\hline $\begin{array}{l}\text { Marital } \\
\text { status }\end{array}$ & $\begin{array}{l}\text { Mean } \\
\text { value }\end{array}$ & F value & t value & P value & Result \\
\hline Married & 70.7879 & & & & \\
& & 17.544 & -1.703 & $0.000^{*}$ & Significant \\
Unmarried & 72.9000 & & & & \\
\hline
\end{tabular}

Source: Primary data, *At $1 \%$ level of significance **At $5 \%$ level of significance.

The one way ANOVA Table - 14 reveals that there is no significant difference between marital status of sample bank personnel and their perceptions and attitudes toward financial inclusion process in India. Therefore, both married and unmarried bank personnel have same level of perceptions and attitudes toward financial inclusion process in India. Mean scores show that Unmarried bank personnel have more positive perceptions and attitudes (72.90) toward financial inclusion process in India than married bank personnel (70.78).

Table 15. Education And Perceptions And Attitudes Of Bank Personnel Toward Financial Inclusion Process In India.

\begin{tabular}{lllll}
\hline Education & $\begin{array}{l}\text { Mean } \\
\text { Value }\end{array}$ & F value & P Value & Result \\
\hline UG & 71.8333 & & & \\
PG & 72.2051 & 141 & 0.995 & $\begin{array}{l}\text { Not } \\
\text { Significant }\end{array}$ \\
Professional Qualification & 72.1778 & & & \\
\hline
\end{tabular}

Source: Primary data, *At 1\% level of significance **At $5 \%$ level of significance.

The above ANOVA Table - 15 shows that there is no significant difference between educational qualification of sample bank personnel and their perceptions and attitudes toward financial inclusion process in India. Therefore, bank 
personnel have same level of perceptions and attitudes toward financial inclusion process in India irrespective of their educational qualification. Mean scores show that bank personnel with post graduate degree have more positive perceptions and attitudes (72.20) toward financial inclusion process in India than bank personnel with professional qualification (72.17) and bank personnel with under graduate degree (71.83).

Table 16. Designation and perceptions and attitudes of bank personnel toward financial inclusion process in India.

\begin{tabular}{lllll}
\hline Designation & Mean Value & F value & P Value & Result \\
\hline Branch Officer & 77.0196 & & & \\
Branch Accountant & 68.0000 & 128.605 & $0.000^{*}$ & Significant \\
Branch Manager & 70.6667 & & & \\
\hline
\end{tabular}

Source: Primary data, *At $1 \%$ level of significance **At $5 \%$ level of significance.

The One way ANOVA Table - 16 shows that there is significant difference between designation of sample bank personnel and their perceptions and attitudes toward financial inclusion process in India. Therefore, bank personnel's perceptions and attitudes financial inclusion process in India differ on the basis of their designation. Mean scores show that branch accountants have least perceptions and attitudes (68.00) toward financial inclusion process in India. On the other hand, branch officers have more positive perceptions and attitudes (77.01) toward financial inclusion process in India and branch managers exhibit moderate positive perceptions and attitudes (70.66) toward financial inclusion process in India.

Table 17. Years of service and perceptions and attitudes of bank personnel toward financial inclusion process in India.

\begin{tabular}{lllll}
\hline Years of service & Mean Value & F value P Value & Result \\
\hline Less than 15 years & 70.6357 & & & \\
16 years to 30 years & 78.3030 & 1.262 & 0.286 & Not Significant \\
More than 30 years & 71.8333 & & & \\
\hline
\end{tabular}

Source: Primary data, *At $1 \%$ level of significance **At $5 \%$ level of significance.

The above ANOVA Table - 17 shows that there is no significant difference between years of service by sample bank personnel and their perceptions and attitudes toward financial inclusion process in India. Therefore, bank personnel have same level of perceptions and attitudes toward financial inclusion process in India irrespective of their number of years of service. Mean scores show that bank personnel with 16 years to 30 years have more positive perceptions and attitudes (78.30) toward financial inclusion process in India than bank personnel with more than 30 years of service (71.83) and bank personnel with less than 15 years of service (70.63).

Table 18. Place of native and perceptions and attitudes of bank personnel toward financial inclusion process in India.

\begin{tabular}{lllll}
\hline Place of native & Mean Value & F value & P Value & Result \\
\hline Remote area & 68.0000 & & & \\
Rural area & 73.3333 & 409.454 & $0.000^{*}$ & Significant \\
Urban area & 70.6667 & & & \\
Metropolitan & 72.2759 & & & \\
\hline
\end{tabular}

Source: Primary data, *At 1\% level of significance **At 5\% level of significance.

The ANOVA Table - 18 shows that there is significant difference between native place of sample bank personnel and their perceptions and attitudes toward financial inclusion process in India. Therefore, bank personnel's perceptions and attitudes financial inclusion process in India differ on the basis of their native place. Mean scores show that bank personnel whose native place is remote area, have least perceptions and attitudes (68.00) toward financial inclusion process in India. On the other hand, bank personnel whose native place is rural area have more positive perceptions and attitudes (73.33) financial inclusion process in India followed by bank personnel whose native place is metropolitan (72.27) and bank personnel whose native place is urban area (70.66).

Table 19. Economic status of family and perceptions and attitudes of bank personnel toward financial inclusion process in India.

\begin{tabular}{lllll}
\hline $\begin{array}{l}\text { Economic status } \\
\text { of family }\end{array}$ & Mean Value & F value & P Value & Result \\
\hline Well off & 74.6667 & & & \\
Middle Class & 71.9683 & 2.565 & $0.023^{* *}$ & Significant \\
Poor & 71.6190 & & & \\
\hline
\end{tabular}

Source: Primary data, *At 1\% level of significance **At 5\% level of significance.

The ANOVA Table - 19 shows that there is significant difference between economic status of sample bank personnel's family before employment and their perceptions and attitudes toward financial inclusion process in India. Therefore, bank personnel's perceptions and attitudes financial inclusion process in India differ on the basis of the economic status of their family before employment. Mean scores show that bank personnel who belonged to poor 
family show least perceptions and attitudes (71.61) toward financial inclusion process in India. On the other hand, bank personnel who were well off, show more positive perceptions and attitudes (74.66) toward financial inclusion process in India followed by bank personnel who were poor (71.96).

Table 20. Type of bank and perceptions and attitudes of bank personnel toward financial inclusion process in India.

\begin{tabular}{lllll}
\hline Type of Bank & Mean Value & F value & P Value & Result \\
\hline Public sector bank & 72.8762 & & & \\
Private sector bank & 71.4167 & 10.432 & $0.000 *$ & Significant \\
Regional rural bank & 70.9091 & & & \\
\hline
\end{tabular}

Source: Primary data, *At 1\% level of significance **At $5 \%$ level of significance.

The ANOVA Table - 20 shows that there is significant difference between types of bank in which sample bank personnel work and their perceptions and attitudes toward financial inclusion process in India. Therefore, bank personnel's perceptions and attitudes toward financial inclusion process in India differ on the basis of types of bank where they work. Mean scores show that bank personnel who work in Public sector bank show more positive perceptions and attitudes (72.87) toward financial inclusion process in India. On the other hand, bank personnel who work in Private sector bank show moderate positive perceptions and attitudes (71.41) toward financial inclusion process in India and bank personnel who work in regional rural bank show least positive perceptions and attitudes (70.90) toward financial inclusion process in India.

Table 21. Location of bank and perceptions and attitudes of bank personnel toward financial inclusion process in India.

\begin{tabular}{lllll}
\hline Location of Bank & Mean Value & F value & P Value & Result \\
\hline Remote area & 72.5217 & & & \\
Rural area & 76.8485 & 7.545 & $0.000^{*}$ & Significant \\
Semi-urban area & 72.0000 & & & \\
Urban area & 69.5652 & & & \\
\hline
\end{tabular}

Source: Primary data, *At $1 \%$ level of significance **At $5 \%$ level of significance.

The ANOVA Table - 21 shows that there is significant difference between location of bank where sample bank personnel work and their perceptions and attitudes toward financial inclusion process in India. Therefore, bank personnel's perceptions and attitudes toward financial inclusion process in India differ on the basis of location of bank where they work. Mean scores show that bank personnel who work in rural area bank show more positive perceptions and attitudes (76.84) toward financial inclusion process in India followed by bank personnel who work in remote area bank (72.52). On the other hand, bank personnel who work in urban area bank show least positive perceptions and attitudes (69.56) toward financial inclusion process in India followed by bank personnel who work in semi-urban area (72.00).

Differences in perceptions and attitudes of sample bank personnel toward financial inclusion process in India on the basis of their demographic and work related variables are analyzed and discussed in tables - 5.12 to 5.21 using Students " $t$ " test and one way ANOVA (F test). Based on such analysis, comprehensive conclusions can be evolved about perceptions and attitudes of sample bank personnel toward financial inclusion process in India which are as follows:

The study results exhibit that female unmarried bank personnel born in rural area, irrespective of his age, educational qualification and years of service, having well off economic status before her employment, but, works as branch officer in public sector rural area bank shows higher positive level of perception and attitude towards financial inclusion process in India.

On the other hand, married male bank personnel born in urban area, irrespective of his age, educational qualification and years of service, having poor economic status before his employment, but, works as branch accountant in regional rural bank in urban area shows lowest positive level of perception and attitude towards financial inclusion process in India.

\subsection{Multiple Stepwise Regression}

Multiple step wise regression is a statistical technique that can be used to analyze the relationship between a single dependent (criterion) variable and several independent (predictor) variables. The objective of multiple regression analysis is to use independent variables whose values are known to predict value of single dependent value selected.

\subsubsection{Impact of Perceptions and Attitudes of Bank Per- sonnel towards Financial Inclusion Process in India on Perceptions and Attitudes of Bank Personnel towards Provision of Credit to Poor}

Hypothesis

H0: There is no significant impact of perceptions and attitudes of bank personnel towards financial inclusion process in India on perceptions and attitudes of bank personnel towards provision of credit to poor,

H1: There is a significant impact of perceptions and attitudes of bank personnel towards financial inclusion process in India on perceptions and attitudes of bank personnel towards provision of credit to poor,

In this part of the analysis, perceptions and attitudes of bank personnel towards provision of credit to poor and independent variable is entered in step wise regression analysis. The independent variable is perceptions and attitudes of 
bank personnel towards financial inclusion process in India and the dependent variable is perceptions and attitudes of bank personnel towards provision of credit to poor.

The Table - 22 shows the model summary for the $R, R^{2}$, adjusted $R^{2}$ and standard error of the estimate. The $R^{2}$ value indicates the percent of variance in the criterion (dependent variable) that is accounted for by the linear combination of predictor (independent) variables. Model 1 has $\mathrm{R}^{2}$ value of .148 which indicates the variance accounted for by the linear combination of perceptions and attitudes of bank personnel towards financial inclusion process in India.

Table 22. Model summary.

\begin{tabular}{lllll}
\hline Model & $\mathbf{R}$ & $\mathbf{R}^{2}$ & Adjusted $\mathbf{R}^{2}$ & Std. error of the estimate \\
\hline 1 & $.385^{\mathrm{a}}$ & .148 & .134 & 6.54163 \\
\hline
\end{tabular}

a. Predictors: (Constant), Perceptions and attitudes of bank personnel towards financial inclusion process in India.

Table 23. ANOVA (b).

\begin{tabular}{|c|c|c|c|c|c|}
\hline \multicolumn{2}{|c|}{ MODEL } & \multirow{2}{*}{$\begin{array}{l}\begin{array}{l}\text { Sum } \\
\text { of squares }\end{array} \\
447.225\end{array}$} & \multirow{2}{*}{$\begin{array}{l}\text { Df } \\
1\end{array}$} & Mean square & Significance \\
\hline \multirow{3}{*}{1} & Regression & & & 447.225 & \multirow{3}{*}{$1^{10.45} .002^{\mathrm{a}}$} \\
\hline & Residual & 2567.576 & 60 & 42.793 & \\
\hline & Total & 3014.801 & 61 & & \\
\hline
\end{tabular}

a. Predictors: (Constant), Perceptions and attitudes of bank personnel towards financial inclusion process in India.. b. Dependent Variable: Perceptions and attitudes of bank personnel towards provision of credit to poor.

The Table -24 shows that selected independent variable namely perceptions and attitudes of bank personnel towards financial inclusion process in India has significant impact on perceptions and attitudes of bank personnel towards provision of credit to poor. The one way ANOVA (F test) in the table -23 for model -1 is also statistically significant. Therefore, it can be concluded that perceptions and attitudes of bank personnel towards financial inclusion process in India have significant impact on perceptions and attitudes of bank personnel towards provision of credit to poor. Further, perceptions and attitudes of bank personnel towards financial inclusion process in India have positive impact on perceptions and attitudes of bank personnel towards provision of credit to poor (Beta score is 0.385 ).

Table 24. Co-efficients ${ }^{a}$.

\begin{tabular}{|c|c|c|c|c|c|c|}
\hline \multirow[t]{2}{*}{ MODEI } & & \multicolumn{2}{|c|}{$\begin{array}{l}\text { Unstandardized } \\
\text { coefficients }\end{array}$} & \multirow{2}{*}{$\begin{array}{l}\text { Standar-dized } \\
\text { coefficients } \\
\text { Beta } \\
\end{array}$} & \multirow[t]{2}{*}{$\mathbf{T}$} & \multirow[t]{2}{*}{ Sig. } \\
\hline & & B & Std. error & & & \\
\hline & Constant & 31.001 & 12.766 & & 2.428 & .018 \\
\hline 1 & $\begin{array}{l}\text { Perceptions } \\
\text { and attitudes } \\
\text { of bank } \\
\text { personnel } \\
\text { toward } \\
\text { financial }\end{array}$ & .571 & .177 & .385 & 3.233 & .002 \\
\hline
\end{tabular}

inclusion

a. Dependent Variable: Perceptions and attitudes of bank personnel towards provision of credit to poor.

Since perceptions and attitudes of bank personnel toward financial inclusion process in India have positive impact on perceptions and attitudes of bank personnel towards provision of credit to poor, bankers and Reserve Bank of India should take necessary initiatives to increase positive perceptions and attitudes of bank personnel toward financial inclusion process in India in order to serve the poor in a better way and to bring the poor in substantial number in to formal financial system.

\section{Conclusion}

This article has analyzed empirically, based on demographic and work related characteristics, perceptions and attitudes of bank personnel towards provision of credit to poor and perceptions and attitudes of bank personnel toward financial inclusion process in India.

Based on empirical results and interpretations, the following profiles of the bank personnel are developed with regard to perceptions and attitudes of bank personnel towards provision of credit to poor and perceptions and attitudes of bank personnel toward financial inclusion process in India.

\subsection{Perceptions and Attitudes of Bank Personnel towards Provision of Credit to the Poor}

The study results exhibit that the bank personnel born in urban area, who may be either male or female and either married or unmarried, irrespective of his age, educational qualification and years of service, having well off economic status before his employment, but, works as branch accountant in public sector rural area bank shows higher positive level of perception and attitude towards provision of credit to the poor.

Conversely, the bank personnel born in remote area, who may be either male or female and either married or unmarried, irrespective of his age, educational qualification and years of service, having middle class economic status before his employment, but, works as branch manager in regional rural bank in remote area shows lowest positive level of perception and attitude towards provision of credit to the poor.

\subsection{Perceptions and Attitudes of Bank Personnel toward Financial Inclusion Process in India}

The study results exhibit that female unmarried bank personnel born in rural area, irrespective of his age, educational qualification and years of service, having well off economic status before her employment, but, works as branch officer in public sector rural area bank shows higher positive level of perception and attitude towards financial inclusion process in India. 
Conversely, married male bank personnel born in urban area, irrespective of his age, educational qualification and years of service, having poor economic status before his employment, but, works as branch accountant in regional rural bank in urban area shows lowest positive level of perception and attitude towards financial inclusion process in India.

Regression analysis result depicts that:

Perceptions and attitudes of bank personnel towards financial inclusion process in India have significant impact on perceptions and attitudes of bank personnel towards provision of credit to poor. Further, perceptions and attitudes of bank personnel towards financial inclusion process in India have positive impact on perceptions and attitudes of bank personnel towards provision of credit to poor.

\section{References}

[1] Short, C., (2000) Foreword to Rutherford, S. "The Poor and their Money", New Delhi: Oxford University Press.

[2] Marr, A, (1999), "The poor and their money: What have we learnt?" ODI Poverty Briefing, London: Overseas Development Institute.

[3] Shylendra, H. S. (1994a), "Lender vitality and lender behavior: A case-study of a Regional Rural Bank in South India", Working Paper 70, Anand: Institute of Rural Management.

[4] Jones, J. H. M. (1994), "A changing financial landscape in India: Macro-level and micro-level perspectives", in F.J.A. Bouman, \& O. Hospes (Eds.), Financial Landscapes Reconstructed (pp. 305-324), Boulder, San Francisco, and Oxford: Westview Press.

[5] Thorat, Y. S. P. (1999), "Status and prospects of microfinance in India", paper presented at the Third Annual Seminar on
New Development Finance, Goethe University, Frankfurt.

[6] McGregor, J. A. (1988), "Credit and the rural poor: The changing policy environment in Bangladesh", Public Administration and Development, 9, pp. $467-482$.

[7] McKee, K. (1989), "Micro level strategies for supporting livelihoods, employment and income generation of poor women in the third world: The challenge of significance", World Development, 17(7), 993-1006.

[8] Baydas, M. M., Graham, D. H., \& Valenzuela, L. (1997), "Commercial Banks in microfinance: New actors in the microfinance world", Microfinance World, Microenterprise Best Practices, Development Alternatives, Inc.

[9] Wright, G. A. A (2000), "Microfinance systems: Designing quality financial services for the poor", Dhaka: Zed Books.

[10] Johnson, S., \& Rogaly. (1997), "Microfinance and poverty reduction", Oxford: Oxfam Publications.

[11] Jones, J. H. M., \& O. Sakyi-Dawson (2002), "Linking formal and informal financial intermediaries in Ghana: A way to increase women's access to financial services?" in B. Lemire, R. Pearson, and G. Campbell (Eds.), Women and Credit, Researching the Past and Refiguring the Future (pp. 271 294 ), Oxford and New York: Berg.

[12] K.C. Chakrabathy, (2011), "Financial inclusion and banks issues and perspectives" at FICCI and UNDP conference on financial inclusion: partnership banks, MFIs and communities.

[13] Dr Subbarao D, Governor, RBI, Dec 2009. Keynote address on "Financial Inclusion: Challenges and opportunities" at the Bankers Club in Kolkata.

[14] Thorat Usha, DG, RBI, Sep 2010. Keynote address at a panel session on "Setting New Paradigm in Regulation" at the FICCI-IBA Conference on 'Global Banking: Paradigm Shift'. 